https://doi.org/10.18485/cosic_dobrica.2018.ch16

821.163.41.09-31 Ћосић Д.

821.163.41.03=163.2

821.163.41.09(497.2)

\author{
БРАНКО С. РИСТИЋ* \\ Универзитет у Приштини \\ Учитељски факултет (Лепосавић)
}

\title{
РЕЦЕПЦИЈА ПРОЗЕ ДОБРИЦЕ ЋОСИЋА У БУГАРСКОЈ
}

\begin{abstract}
У раду се, применом компаративног и аналитичког метода, разматра рецепција стваралаштва Добрице Ћосића у Бугарској. Анализирају се преводи романа „Корени” и „Деобе”. Даје се библиографија превода текстова и књига Д. Ћосића, као и библиографија радова о Д. Ћосићу бугарских критичара. Циљ рада је да се укаже на велики значај преведених романа и њихово прихватање од стране бугарског читаоца, као и на прожимање српске и бугарске књижевности. Задатак рада је истражити рецепцију превода Ћосићевих романа на бугарском језику и став бугарске књижевне критике о тим романима.
\end{abstract}

Кључне речи: рецепција дела, Добрица Ћосић, компаративистика, превод, рецензија, библиографија.

Време после II светског рата у Бугарској доноси нагли развој упоредног проучавања култура суседних народа, а нарочита пажња поклања се књижевности. Кроз овакав начин деловања почела су да се нуде нова решења важних путева историје и теорије упоредних књижевности, међу којима је и кључно питање типолошкх сличности и генетских веза књижевности разних народа, па и српског и бугарског, питање рецепције као процеса рецепције, одн. прихватања појединих писаца и дела. Све ово напред наведено врло је важно и значајно и само половично обухвата суштину рецепције текста Добрице Ћосића, независно од тога што видне компоненте овог питања остају изван видокруга опширног тумачења проблема. У случају Ћосићевог текста, а у питању су два романа, Корени и Деобе, компоненте које чине садржај и спајају оно што је особено у овој рецепцији јесу:

1. Непосредна и посредна зависност између ова два романа и личност њиховог аутора; 2. Појединачна зависност прихватања Ћосића и форма рецепције његових романа;

\footnotetext{
*braris9@gmail.com
} 
3. Особености рецепције Ћосићевих романа и историјско време њихове појаве и њихово рецепцирање у Бугарској; 4. Психолошки контекст дела, његових јунака и појединаца.

Када заронимо у садржај и суштину особености рецепције Ћосићевог текста у суседној Бугарској, ваља истаћи следеће: своју посебност има рецепција романа Корени, а своју посебност роман Деобе. Обе ове посебности заснивају се на традиционалним формама њиховог прихватања и поимања које су, у принципу, врло сличне: библиографија, квалитет превода, оцена критике, признања и награде писца. У Ћосићевом случају од великог значаја су биле и његове професионалне и персоналне везе успостављене преко тадашњих институција двеју земаља.

Почетак рецепције књижевног дела Добрице Ћосића у Републици Бугарској поклапа се баш са временом отопљавања југословенскобугарских односа после резолуције Информбироа (1948-1953). Дакле,

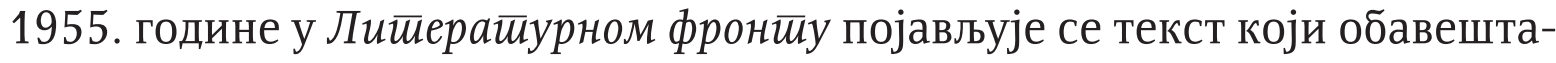
ва бугарску културну јавност да је Добрица Ћосић добитник престижне

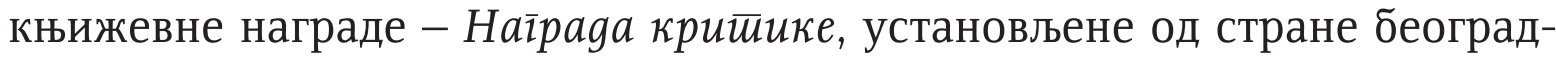
ског недељника НИН, за роман Корени, који је проглашен за најбољи

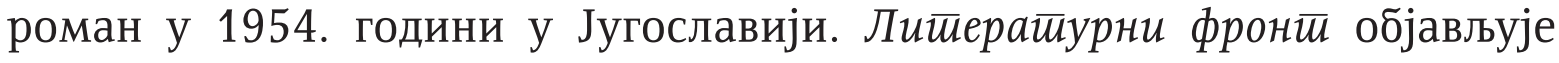
кратку биографију Добрице Ћосића и део његовог интервјуа у НИН-у поводом награде. У наведеном интервјуу у заглављу је наведен кључни део: „Окренуо сам се прошлости, да бих могао да разумем боље будућност. Вратио сам се у прошлост, да бих могао да разумем боље наше страсти и слабости... Наша прошлост представља велику драму и ја сам један од тих, који се труди да осветли једну њену тамну страну" (Ћосић 1956: 4). Информација коју тада добија бугарска читалачка публика о Ћосићу претходи преводу романа Корени на бугарски језик и буди велико интересовање за нашег писца и његово дело. Његово стваралачко исповедање у том интервјуу, преузетом из НИН-а, и његово схватање смисла о васкрсавању прошлости наилазе на плодно тле у Бугарској и врло успешно бивају прихваћени од стране бугарске књижевне критике и читавог бугарског друштва уопште у то време, када су још увек врло живе и гласне полемике и дискусије о тек објављеним романима Дуван Димитра Димова (1951) и Гвозgени свеииионик Димитра Талева (1952).

Ћосићев роман Корени (1954) преведен је на бугарски језик 1956. године. Роман је превео Љубен Божинов, који је као најаву пред изла-

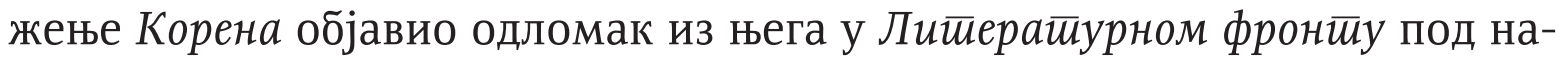

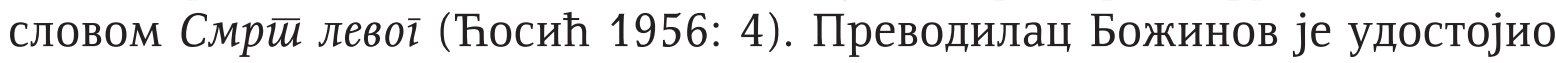
бугарске читаоце једним коректним предговором, у коме на почетку описује место Добрице Ћосића у југословенској књижевности и истиче његову изненадну, али импресивну појаву потенцирајући да је он „врло 
зрео и велики писац". Садржај романа је скициран са мером, таман толико да испроворцира читаоца, преводилац истиче специфичне особености пишчевог приступа, који изузетно добро „користи историјски моменат само као средство да објасни извесне појаве у друштвено-политичком развоју свога народа и на тај начин заправо избегава писање историјског романа, већ ствара социо-психолошки роман" (Ћосић 1956: 11). Преводилац истиче да је за читаоца врло важна представа о самом књижевном тексту и сагледавање основних идеја које он у себи носи: промашену љубав и милосрђе, жестоку и беспоштедну политичку борбу, одбацивање предрасуда и оригиналност вечитих питања о животу и смрти. Даље у предговору говори о оргиналности и привлачности Ћосићевог стила, али истовремено, тиме Божинов као преводилац истиче и свој суд да „никако није лак за превод и на одређеним местима је чак и изазован" (Ћосић 1956б: 12). Његова анализа пишчеве пристрасности ка коришћењу ретроспекције и максималном сабијању догађаја и често мешање глаголских времена показују се не баш као нека специфичност Ћосићевог стила као великог писца, што Божинов истиче, колико као извесна пажња за евентуални неуспех у преводу романа. Уосталом, читалац то види при читању самог предговора, који је пун нејасних и незграпних фраза, тромих реченичних исказа, које бацају сенку на неоспорно јасне, верне и врло високе оцене о аутору и самом роману. Покушај преводиоца Божинова да на крају предговора сугерише како „неке реченичне конструкције које се срећу у тексту, донекле не одговарају нормама бугарског стила и језика, те су остављене по изричитој жељи писца да буду такве какве јесу" (Ћосић 1956б: 13) никако не поправља утисак да превод романа Корени Добрице Ћосића, најблаже речено, није баш срећно урађен.

Бугарска књижевна јавност и критика (Ганчо Савов, Милена Цанева, Бојан Ничев, Стефана Елефтеров...) данас сматрају да је превод романа Корени Добрице Ћосића од стране Љубена Божинова књижевно-историјски факт, догађај који је имао снажан одјек у Бугарској у то време. Једног великог српског писца даривао је бугарском читаоцу, то је уистину велики чин, али нажалост и истина је да са оваквим преводом овај роман није представљен тако како је требало да буде. Врло често се у бугарском преводу срећу одређени изрази и цели одломци који на бугарском звуче неправилно и читаоца враћају на поновно читање, и то по неколико пута, да би могли да се разумеју и схвате, терајући читаоца да почне сам да их goūpeвоgu. У бугарској штампи нису се у то време појавили посебни прикази и критике о роману и преводу бугарског издања Корена. Оно на што ваља скренути пажњу јесте да су сва она места у роману која су незграпно и трапаво преведена бугарс- 
кој књижевној критици остала у сећању. Када се после једне деценије, 1966. године - Божинов у коауторству са Д. Божиновом - јавио да ради на новом преводу новог Ћосићевог романа Деобе и објавио једну главу из романа, критика и људи који су се бавили и српском литературом између осталог (Конев, Савов, Цанев, Марков, Ничев, Елефтеров), без имало задршке изазили су нескривену сумњу у преводилачке способности Божинова. Велики познавалац у то време српске књижевности, професор Софијског универзитета Бојан Ничев, у изванредном тексту

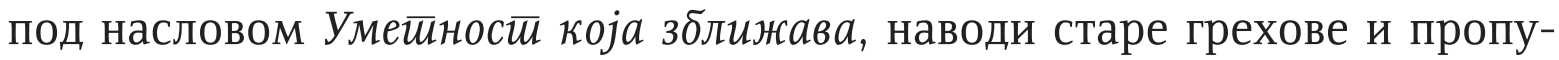
сте преводиоца романа Корени и са врло јаким аргументима наводи бугарској читалачкој јавности недопустиве пропусте у преводу одломка С̄̄pax из романа Деобе. Професор Ничев све то темељно и разложно показује цитирајући примере оба превода (Корени, одломак из Деоба) који непобитно показују непрецизност, непознавање српског језика и заводљиво увођење у језичке конструкције, под утицајем блискости два језика. Професор Ничев у свом тексту јасно истиче да је нови превод Љ. Божинова, одломка из Ћосићевих Деоба, „само подстрек на читање једног интересантног уметничког дела" (Ћосић 1965: 4). Ничев даље у истом тону наставља и истиче да није мали пропуст преводилаца који не обраћају пажњу на уметничке акценте у датој фрази, који објашњавају и обогаћују замисао аутора кроз вишезначности подтекста, који је скривен у датом изразу или речи. Буквални превод је увек био анахронизам и то време у развијању преводилаштва је прошло. Преводилаштво данас је уметност, уметност која тражи адекватност и уметничку праву вредност у односу на оригинал. Са те тачке гледишта, текст проф. Бојана Ничева је заправо, за то време, а и данас, програмски текст који у себи носи анализу свих увређених преводилаца и њихових превода, овај текст даје основне и будуће смернице преводилаштва у Бугарској.

Превод Ћосићевог романа Корени 1956. године на бугарски језик је најзначајније представљање њега као писца, али то није и једини сусрет са њим у то време у Бугарској. Исте те, 1956. године, Ћосић посећује Бугарску као члан југословенске парламентарне делегације, и то изазива велико интересовање тадашње бугарске јавности и појаву неколико

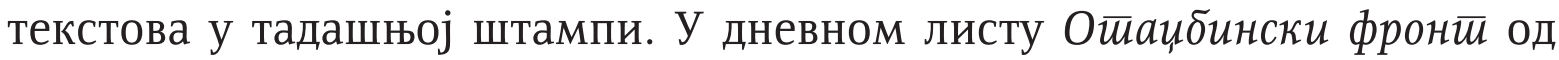
8. априла 1956. године излази Ћосићева кратка биографија и интервју са њим. У том интервјуу он износи неке своје ставове и наводи да је врло важно да човек зна своје корене и историју свога народа и истиче да књижевност има врло значајно место у развоју српско-бугарских односа. У том интервјуу се налази једна врло интересантна мисао, за то време за Бугаре врло несхватљива и вишезначна: „социјална обавеза се даје не из конкретне институције, већ од епохе, која стреми да заштити право стваралачке слободе и индивидуалности". 
У исто то време Вечерње новине објављују његову фотографију са потписом, кратку белешку која објашњава један одломак из романа Далеко је сунще (1951). У белешци се наводи да је овај роман врло значајно његово дело, да је роман већ имао неколико издања, да је преведен на више језика и да је по њему у Србији снимљен филм. Овај одломак који је објављен нема потпис преводиоца, али је превод врло леп и тачан, уредник га је изузетно добро урадио, што га чини читљивим и разумљивим. У истим новинама после неколико дана објављена је и песма Искрен разіовор Љубомира Јорданова, посвећена Ћосићу. Песма није велике уметничке вредности, више звучи као памфлет и један римовани преглед бугарско-српских односа кроз векове. Ако све ово ставимо по страни, сам овај чин привукао је велику пажњу бугарске књижевне јавности према Добрици Ћосићу. Наредних година бугарска књижевна критика је врло често тумачила и говорила о Ћосићевом стваралаштву и његовим естетским схватањима и наводећи суштину његовог уметничког метода, давала различите оцене, али увек са великим поштовањем према њему и његовом делу.

Наредни сусрет бугарске јавности са Ћосићем догодио се тек 1964.

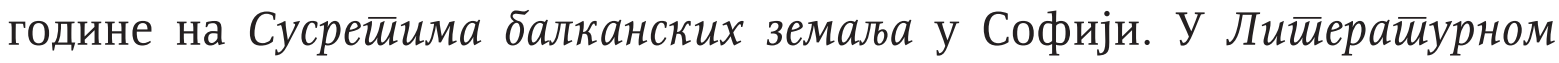
фронйу штампан је резиме његовог обраћања пред сусрете за које он вели да су „позитивни, добри, пуни оптимизма и да праве простор за ширење културног општења на Балкану". Ћосић у овом резимеу, како наводи бугарски новинар, „тражи хумани смисао револуције у друштвеној пракси у стварању услова за слободу личности и за истину у животу, али тако да није јасно да ли мисли да је то нешто већ постигнуто, или га издиже као платформу по којој још има много тога да се жели". Новинар даље наставља, у резимеу се не говори с којим то „једностраним представама о човеку" он није сагласан, али од реченог недвосмислено се види ослобођено мишљење Ћосића по многим питањима, које провоцира бугарску јавност да са нестрпљењем очекује следећи сусрет са његовим делом (Ћосић 1967: 4).

Није прошло много времена, бугарска јавност се упознаје са Ћосићевим романом Деобе, који се у Софији објављује 1967. године у преводу Сијке Рачеве. Најаву овог романа срећемо на страницама књижевног часописа Сеййември (1967: 188), где се вели да је овај роман југословенска књижевна критика оценила највишом оценом и да се сматра да је то до сада „најбоље Ћосићево дело”. Даље се наводи да роман тематски слика догађаје из Другог светског рата и немачке окупације, братоубилачки рат, да захвата простор западног поморавља и слика страшно страдање српског народа. У тексту се цитира и мишљење тадашњег главног уредника часописа Савременик. Иако су сви ови наводи и белешке кратки, 
они су ипак врло ефектни и нису безначајни, они су заправо били врло плодно тле за невероватан успех овог романа у Бугарској. Прихватање једног писца и његовог дела на туђем језику у туђој земљи зависи пре свега од припремања и грађења интереса према њему и сондирању терена код читалачке публике за прихватање или проблема којим се тај писац у свом делу бави или изношење вечне општељудске истине.

За позитиван однос тадашње бугарске књижевне критике и бугарског читаоца несумњиво највећу заслугу има предговор роману Деобе из пера Богомила Нонева, који истиче да је то „монументалан” роман, роман који у себи носи политичко-психолошку димензију и баца светлост на Други светски рат у Србији описујући најкрвавије странице новије српске историје.

Успех овог Ћосићевог романа у Бугарској није само Ћосићев бриљантан стил, дубок психологизам већ и изванредан и адекватан превод Сијке Рачеве. „Свеобухватност аутора, широка лепеза стилских подухвата, које он користи понекада са високим стилом драматурга а не белетристе, да би проникао у душу својих хероја и у непредвидљивим догађајима, огроман су изазов за преводиоца" (Ћосић 1964: 9). Овај суд изнесен у предговору Б. Нонева најуверљивије потврђује умеће преводиоца и истинска су препорука будућем читаоцу.

На крају, са сигурношћу се може рећи да рецепција Добрице Ћосића у Бугарској није завршен процес, огроман део његовог стваралаштва, од белетристике, преко есејистике, записа, дневника до публицистике, још увек је непознаница за бугарског читаоца.

Превођењем бар дела књижевног опуса Добрице Ћосића на бугарски језик, бугарској јавности би се дале на увид неопходне информације за разумевање и схватање сложених савремених токова који се одвијају на Балкану.

\section{БИБЛИОГРАФИЈА ДОБРИЦЕ ЋОСИЋА НА БУГАРСКОМ ЈЕЗИКУ}

\section{а) Превоgu}

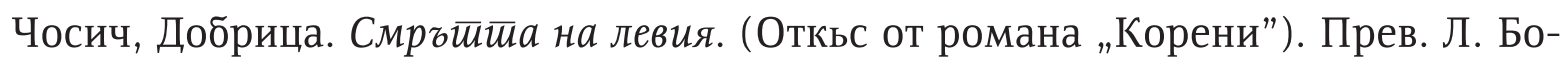

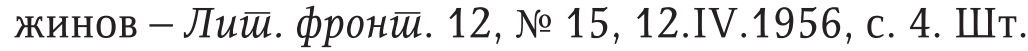

Чосич, Добрица. Корени. Роман. Прев. от сьрбохьрватски Любен Ал. Божинов. София: Нар. култура, 1956. 254 с. Шт.

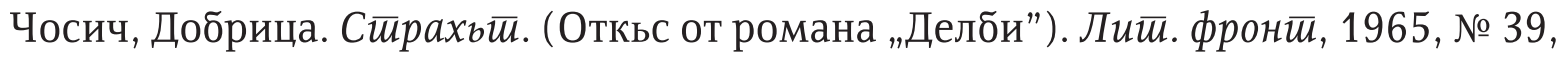
с. 4. Шт. 
Чосич, Добрица. Делби. Роман. Прев. Сийка Рачева (С предг. от Богомил Нонев). София: Нар. култура, 1967. 956 с. Шт.

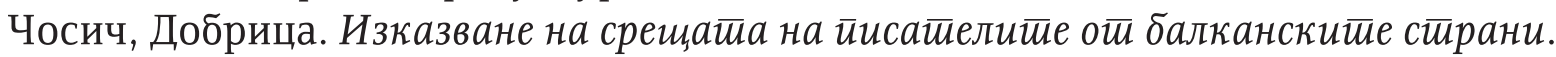

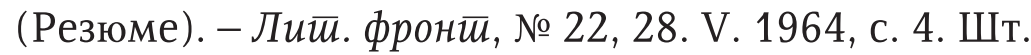

\section{б) Критичка}

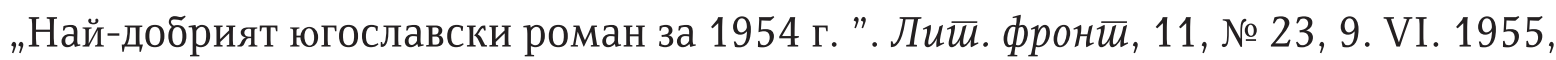
с. 4 . Шт.

Савов, Г. „Признаци на обновление в днешната югославска литература”. Лити. мисъл, 1963, № 3, с. 109. Шт.

Савов, Г. „Реализмът - най-жизненият метод”. Пламък, 1963, № 10, с. 153. Шт. Ничев, Б. „Изкуство, което сближава”. Сейиември, 1967. № 1, с. 106. Шт.

„Нов роман на Добрица Чосич”. (Бележка). Сейиември, 1967, № 1, с. 188. Шт.

Савов, Г. Южнославянскийе литерайури йрез ХХ сйолейие. В. Търново, 2002, с. 45 . Шт.

\section{Извори и литература}

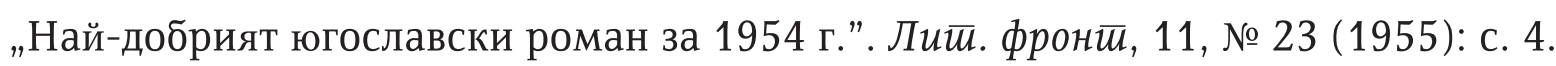
Шт.

Ничев, Боян. „Изкуство, което сближава”. Сейиемерри, № 1 (1967): с. 106. Шт. „Нов роман на Добрица Чосич”. (Бележка). Сейиември, № 1 (1967): с. 188. Шт. Савов, Ганчо. „Признаци на обновление в днешната 2гославска литература”.

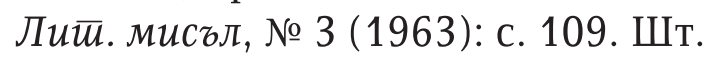

Савов, Ганчо. „Реализмът - най-жизненият метод”. Пламък, № 10 (1963): с. 153. Шт.

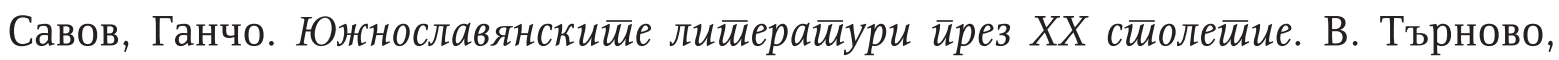
2002, с. 45. Шт.

Чосич, Добрица. Смрғййа на левия. (Откьс от романа „Корени”). Прев. Л. Бо-

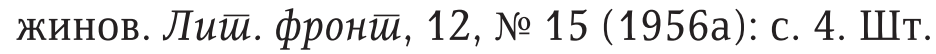

Чосич, Добрица. Корени. Роман. Прев. от сьрбохьрватски Любен Ал. Божинов. София: Нар. култура, 1956б, 254 с. Шт.

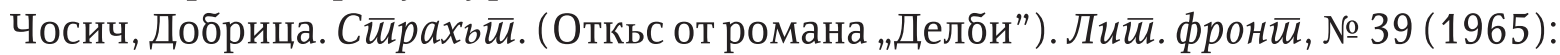
с. 4 . Шт.

Чосич, Добрица. Делби. Роман. Прев. Сийка Рачева (С предг. от Богомил Нонев). София: Нар. култура, 1967, 956 с. Шт.

Чосич, Добрица. „Изказване на срещата на писателите от балканските страни”.

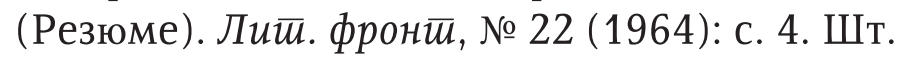


Branko S. Ristić

\title{
THE RECEPTION OF DOBRICA ĆOSIĆ'S FICTION IN BULGARIA
}

\begin{abstract}
Summary
Drawing on the comparative and analytical methods, the paper discusses the reception of Dobrica Ćosićs writings in Bulgaria. It analyses the translations of the novels Roots and Divisions. It also furnishes a bibliography of translations of texts and books by D. Ćosić, as well as a bibliography of papers on D. Ćosić by Bulgarian critics. The paper points to the great importance of the translated novels and their acceptance by the Bulgarian readers, as well as to the ties of Serbian and Bulgarian literature. The aim of the paper is to research the reception of translations of Ćosić's novels in Bulgarian and the attitude of Bulgarian literary criticism towards those novels.
\end{abstract}

